\title{
Home-Grown Recipe for Fast-Tracking Sustainable Development in Nigeria
}

\author{
Muftau Adesina Abayomi \\ Department of Economics, School of Management Technology \\ Federal University of Technology, P.M.B. 704 Akure, Nigeria \\ Oluyemi Philip Ologunwa \\ Department of Economics, School of Management Technology \\ Federal University of Technology, P.M.B. 704 Akure, Nigeria
}

\begin{abstract}
In spite of Nigeria's rich human and natural resources endowment, endemic corruption has constituted a serious impediment to sustainable development. Nigeria was ranked 148 out of 180 countries in 2017 by the Transparency International's Corruption Perceptions Index, which shows that the country is very corrupt. The application of false paradigm model of faulty and inappropriate advice provided by well-meaning but often uninformed and biased international expert advisers has also exacerbated Nigeria's underdevelopment. This paper reviews some theories of growth and development and identifies corruption as a bane of sustainable development in Nigeria. It also postulates a home-grown recipe for accelerating sustainable development in Nigeria to include: forward integration of primary industries and backward integration of manufacturing industries, economic diversification, zero tolerance for and stiffer penalty against corruption at the household, firm and government levels. Therefore, a strict execution of the above would go a long way in fast-tracking sustainable development in Nigeria and thereby make the country one of the most desirable destinations in the world.
\end{abstract}

Keywords: Corruption, Recipe, Growth and development theories, Sustainable development, Nigeria

DOI: $10.7176 / \mathrm{JESD} / 12-16-03$

Publication date:August $31^{\text {st }} 2021$

\subsection{Introduction}

After over five decades of independence, Nigeria is still struggling to achieve sustainable development which has become a mirage. With a Gross Domestic Product of USD 578 billion as at 2014, Nigeria became the largest economy in Sub-Saharan Africa (Oyesola, 2016). However, the country has been performing below its potential while the economy has remained largely mono-cultural. Nigeria has been battling with a number of challenges militating against the achievement of sustainable development. First, the economy is yet to achieve the necessary structural changes required to jump-start rapid and sustainable growth and development. It is also characterized by narrow productive base and weak sectoral linkages (Abasilim, Ayoola \& Odeyemi, 2017). They further aver that primary production comprising agriculture, mining and quarrying (inclusive of oil and gas) dominates national output and the contribution of the manufacturing sector is small in terms of gross output, contribution to growth, foreign exchange earnings, government revenues and employment generation. Furthermore, the business environment has also been unfriendly largely because of epileptic power supply, insecurity and unfavourable policies. Against this backdrop, many manufacturing firms have relocated to countries with a more conducive business climate. York (2015) also notes that the Nigerian currency is weakening, government revenue has dropped dramatically, civil servants' salaries are delayed, many construction projects have been suspended and layoffs have begun.

In spite of rich human and natural resource endowment, corruption has also been a major challenge facing Nigeria today. The Transparency International [TI] (1995) defines corruption as "the abuse of public office for private gain". Nigeria was ranked 148 out of 180 countries in 2017 by the Transparency International's (TI) Corruption Perceptions Index, which shows that the country is very corrupt. The former British Prime Minister, David Cameron, was quoted as describing Nigeria as a "fantastically corrupt country" (The Sun, 2016). This implies that meeting Goal 16, "Peace, Justice and Strong Institutions", is a great challenge. Goal 16 includes commitments to fight corruption, increase transparency, tackle illicit financial flows and improve access to information (TI, 2018). The organization further avers that while Goal 16 itself is not due for comprehensive review until 2019, there is a broad consensus that without meaningful action to reduce corruption, progress towards the other sustainable development (SDG) goals is likely to be extremely limited. Corruption represents a major obstacle to reaching all the SDG goals as it hampers economic growth and increases poverty, depriving the most marginalized groups of equitable access to vital services such as healthcare, education, and water and sanitation (TI, 2018).

The application of false paradigm model of faulty and inappropriate advice provided by well-meaning but 
often uninformed and biased international expert advisers from developed country assistance agencies and multinational donor organizations (Todaro \& Smith, 2011) has also exacerbated Nigeria's underdevelopment. The majority of the Nigerian people are suffering from chronic welfare retardation with increase in the number of vulnerable groups. Also, the over-reliance of many states on statutory revenue allocations has been a matter of serious concern. This is because the allocations are also exposed to the vicissitudes in international oil price and other economic shocks. Meanwhile, the internally generated revenue potential of the states has not been fully harnessed.

Corruption has also dealt devastating blows on the citizenry, both within and outside the country; Nigerians are viewed with suspicion all over the world, while other nationals are cynical about any transaction involving Nigerians. It has become a threat to accelerated development as funds that ought to be judiciously applied in a pareto-optimal way are siphoned into private accounts (Abayomi \& Omoyeni, 2015).

The World Bank (1997) also notes that corruption is bad for development; it leads governments to intervene where they need not and it undermines their ability to enact and implement policies in the areas in which government intervention is clearly needed - whether environmental regulation, health and safety regulation, social safety nets, macroeconomic stabilization or contract enforcement.

According to Pearce and Warford (1993), sustainable development is the pattern of social and structural economic transformation that optimizes available societal benefits in the present without jeopardizing the likely potentials for similar benefits in future. Repetto (1986) defines sustainable development as a development strategy that manages all assets, natural and human resources as well as financial and physical assets, for increasing long-term wealth and well-being. Also, the World Commission on Environment and Development otherwise known as the Brundtland Commission (1997) defines sustainable development as the kind of development that meets the needs of the present generation without compromising the ability of future generations to meet their own needs. Sustainable development relates to an economy's ability to maintain living standards through time, while it should be emphasized that growth in Gross Domestic Product (GDP) per capita is no assurance for long-run sustainability (Aidt, 2010).

Consequently, the objective of this paper is to postulate a home-grown recipe for fast-tracking sustainable development in Nigeria. This paper would add significant value to the extant literature on sustainable development. The study would also provide good reference and resource base for major stakeholders such as governments and policymakers with a view to facilitating sustainable development in Nigeria.

The remainder of this paper is organized as follows: section two deals with the review of theories/models of growth and development while section three discusses a home-grown recipe for fast-tracking sustainable development in Nigeria. Section four of the paper wraps up with conclusion and recommendations.

\subsection{Literature Review on Theories of Economic Growth and Development}

A number of growth and development theories propounded by great scholars have been widely discussed in the literature. In as much as they all have merits, they also carry some limitations. Some of the popular growth and development theories reviewed include the classical theory, the neoclassical theory, the endogenous model and the international dependence school of thought.

a) The Classical Theory of Growth and Development

The Classical School originated in England with Adam Smith's inquiry to the nature and causes of wealth of nations. The classical theory of economic growth, which centres on invisible hands, includes the writings of such economists as David Ricardo, Thomas R. Malthus, John Stuart Mill and Jeans Baptiste Say (Fashola, 2001; Jhingan, 2006).

According to the proponents, large savings must be mobilized, and the set of people that are capable of saving are the capitalists and the landlords. The working class is ruled out because their wages are considered too small. The basic features of the classical theory of growth includes laissez faire, capital accumulation as key to economic progress, profit as the stimulus to investment, tendency for profit to decline, and stationary state as the end result of capital accumulation.

A critique of the Classical School include the fact that it: ignores the middle class, neglects the public sector, pays less importance to technology, and has wrong notions about wages and profits.

\section{b) Neo-Classical Model of Growth}

The neo-classical model of growth was first devised by Robert Solow. The neo-classicalists believe that the sources of growth consist of the growth of labour force, growth of capital stock, and growth of productivity or technical progress. Constant returns are assumed for the productivity of labour and capital so that the residual in output growth, after making allowance for the constant returns to labour and capital, is treated as the technical progress, which is assumed to be exogenous (Fashola, 2001). They contend that a sustained increase in capital investment increases the growth rate only temporarily and that the factor essentially determining long run national development is technical progress. Nnanna, Englama and Odoko (2004), based on Solow's analysis of the American data from 1909 to 1949 , observed that $87.5 \%$ of economic growth within the period was 
attributable to technological change and $12.5 \%$ to the increased use of capital. The result of this growth model was that financial institutions had only minor influence on the rate of investment in physical capital and the changes in investment are viewed as having only minor effects on economic growth.

\section{c) Endogenous Growth Theory}

There is a growing body of endogenous growth theories that seek to explain economic growth and technical progress by means of endogenous factors rather than by means of external and conventional factors such as savings, foreign capital inflow, and orthodox fiscal, monetary and commercial trade policies (Fashola, 2001).

The endogenous growth theory was developed in the 1980's by Romer (1986), Lucas (1988), and Rebelo (1991), among other economists, as a response to criticism of the neo-classical growth model (Nwanyanwu, 2010). Factors such as good infrastructural foundation, sound agricultural foundation, favourable social order including functional democratic institutions that promote accountability and transparency in domestic governance, as well as equitable international economic order and mutually beneficial external relationships are being explored in such theories (Fashola, 2001). Jhingan (2006) explains that the endogenous growth model emphasizes technical progress resulting from the rate of investment, the size of the capital stock and the stock of human capital. In an endogenous growth model, Nnanna et al (2004) observed that financial development can affect growth in three ways, which are: raising the efficiency of financial intermediation, increasing the social marginal productivity of capital and influencing the private savings rate. This means that a financial institution can effect economic growth by efficiently carrying out its functions, among which is the extension of credit.

\section{d) The International Dependence Model}

This model gained widespread acceptance in the 1970's especially among the developing countries' intellectuals as a result of increased disenchantment with the stages and the structural change models. Essentially, international dependence models view developing countries as beset by institutional, political, and economic rigidities, both domestic and international, and caught up in a dependence and dominance relationship with rich countries (Todaro \& Smith, 2011).

There are three major streams of thought under the international dependence models (Todaro \& Smith, 2011) viz :

\section{i. The Neocolonial Dependence model \\ ii. The False Paradigm Model \\ iii. The Dualistic-Development Thesis}

\section{i) The Neocolonial Dependence model}

This model attributes the existence and continuance of underdevelopment primarily to the historical evolution of a highly unequal international capitalist system of rich country-poor country relationships (Todaro \& Smith, 2011). According to Fashola (2001), the factors in play in the neocolonial dependence model include:

i. Factor-biased technology, whereby the less-developed countries import inappropriate technology from advanced countries from the point of view of factor endowments of the former;

ii. Monopoly effect whereby multinational corporations that originated from advanced countries dominate the industrial economy of less-developed countries;

iii. Brain drain effect whereby highly skilled manpower from less-developed countries migrate to the moredeveloped countries for better pay, and;

iv. International demonstration effect, whereby the people of less-developed countries copy the lifestyles of those in more-developed thereby increasing the propensity to import goods from advanced countries against the backdrop of unsustainable export earnings of the poor countries.

ii) The False Paradigm Model

The False Paradigm Model attributes underdevelopment to faulty and inappropriate advice provided by wellmeaning but often uninformed, biased, and ethnocentric international expert advisers from developed country assistance agencies and multinational donor organizations (Todaro \& Smith, 2011). This results in unfavourable outcomes and constitutes a setback for the less-developed nations.

\section{iii) The Dualistic Development Thesis}

Dualism represents the existence and persistence of substantial and even increasing divergences between rich and poor nations and rich and poor peoples' on various levels (Todaro \& Smith, 2011). Although research continues, specifically, the traditional concept of dualism embraces four key arguments (Singer, 1970):

1. Different sets of conditions of which some are "superior" and others "inferior" can coexist in a given space;

2. This coexistence is chronic and not merely transitional;

3. Not only do the degrees of superiority or inferiority fail to show any signs of diminishing, but they even have an inherent tendency to increase;

4. The interrelations between the superior and the inferior elements are such that the existence of the superior elements does little or nothing to pull up the inferior elements, let alone "trickle down" to it. In fact, it may actually serve to push it down - to "develop its underdevelopment." 


\section{e) The Doctrine of Balanced Growth}

According Jhingan (2006), Rosenstein-Rodan was the first economist who propounded the theory of balanced growth without using these words in his 1943 article. He averred that the whole of industry to be created in Eastern and South Eastern Europe should be treated and planned like one huge firm or trust. Rosenstein-Rodan (1943) contends that "often Social Marginal Product (SMP) of an investment is different from its Private Marginal Product (PMP) and that when a group of industries is planned together in accordance with their SMP's, the rate of growth of the economy is greater than it would have been otherwise." This is because an average individual entrepreneur is interested only in the PMP of investment and is not likely to have an accurate assessment of its SMP (Jhingan, 2006).

According to Nurkse (1955), vicious circles of poverty are at work in underdeveloped countries which retard economic growth. If, however, they are broken, economic development will follow. To sum up in the words of Lewis (1958), "In development programmes all sectors of the economy should grow simultaneously, so as to keep a proper balance between industry and agriculture and between production for consumption and production for export... the logic of this proposition is as unassailable as its simplicity" (Jhingan, 2006).

The theory of balanced growth has being criticized on the following grounds, among others: no attention is paid to reducing costs, it has failed as a theory of development, it is inapplicable to underdeveloped economies, it is beyond the capabilities of developing countries as well as the fact that simultaneous establishment of a number of industries is likely to raise money and real costs of production, and so make them economically unprofitable in the absence of sufficient capital equipment, skills, cheap power, etc. (Jhingan, 2006).

\section{f) The Unbalanced Growth Model}

The proponents of the doctrine of unbalanced growth posit that investment should be made in selected sectors rather than simultaneously in all sectors of the economy as no underdeveloped economy has the resources in such quantities required to invest simultaneously in all sectors.

According to Jhingan (2006), the concept of unbalanced growth was popularized by Hirschman. He contends that deliberate unbalancing the economy, according to a pre-designed strategy, is the best way to achieve economic growth in an underdeveloped country. He argued that a country can either unbalance the economy with Social Overhead Capital (SOC) or with Directly Productive Activities (DPA).

Some of the shortcomings of the unbalanced growth theory include; inadequate attention to the composition, direction and timing of unbalanced growth, it neglects resistance caused by unbalanced growth, it ignores lack of basic facilities, disregards lack of factor mobility and emergence of inflationary pressures (Jhingan, 2006).

According to Fashola (2001), as a synthesis of economic growth and development theories, the following major factors explain economic growth and development in Nigeria:

i. Appropriate and adequate capital formation is necessary for accelerating the pace of economic development;

ii. Appropriate and adequate manpower skills and functional education needs to be developed in consonance with desirable and optimal pace and pattern of industrial development;

iii. Sound and adequate infrastructural foundation is imperative, especially electricity, transportation and communication, and development-oriented physical planning;

iv. Sound and dynamic agricultural economy is required to ensure food security and promote the comparative or competitive advantages of agro-allied industries for tropical less-developed country;

v. Favourable external economic relationship to ensure that international economic relationships and interactions are mutually beneficial and not exploitative;

vi. Research and development have to be consciously promoted by government in collaboration with the private sector and educational and research institutions towards realizing optimal technical progress for the nation; and

vii. Favourable social order, including security to life and property, functional democratic institutions that will promote accountability, transparency, social justice and equity, and law and order, has to be put in place through genuine democratization process that is most lacking in poorest and least developed nations.

In conclusion, it is pertinent to suggest that home-grown models of growth, devoid of false paradigm, and bereft of backward socio-cultural beliefs should be put together and conscientiously implemented to take Nigeria to the path of sustainable growth and development.

\subsection{Recipe for a Home-Grown Theory of Sustainable Development in Nigeria}

This thesis is an extension of the initial work of Abayomi and Akinwunmi (2016) that employed the HarrodDomar Model to explain the relationship between corruption and sustainable development. The Harrod-Dormar theory of economic growth, states that the rate of growth of Gross Domestic Product (GDP) is determined jointly by the net national savings ratio, and the national capital-output ratio. More specifically, it says that in the absence of government, the growth rate of national income will be directly or positively related to the savings 
ratio, and inversely related to the economy's capital-output ratio (Todaro \& Smith, 2011). That is:

$$
\frac{\Delta \mathrm{Y}}{\mathrm{Y}}=\frac{s}{c}
$$

But s =I/Y (Rebelo, 1991)

Where:

$\Delta \mathrm{Y} / \mathrm{Y}=$ Rate of growth of Gross Domestic Product;

$\mathrm{s}=$ Net national savings ratio; and,

$\mathrm{c}=$ National capital-output ratio.

$\mathrm{I} / \mathrm{Y}=$ Ratio of investment to Gross Domestic Product

Consequently, corruption in the public and private sectors would reduce net national savings ratio as money gets siphoned outside the country. It also tends to increase the national capital-output ratio as padding of investments and other investment-related corrupt practices increase thereby reducing the rate of economic growth. A reduction in the rate of economic growth against the backdrop of increase in population implies a divergence from the attainment of sustainable development, all things being equal.

Hence, to achieve sustainable development, there is need for forward integration of the primary industries and backward integration of manufacturing industries. Nigeria also needs to adopt a family planning policy backed by an Act to reduce the population growth rate. The government must also ensure economic diversification, and take advantage of the complementarities of products. The government should ensure energy security by increasing supply, preferably through the clean and sustainable sources, by both public and private sectors and enhancing physical and financial access while taking a zero tolerance stance against corruption. The latter must be tackled from the household, firm and government levels by stipulating stiffer penalties backed by relevant Acts. Therefore, the current corruption-related Acts need to be amended to include the stiffer penalties as aforementioned. Also, only people of impeccable integrity should be appointed/elected into leadership positions while development plans should professionally-crafted and religiously executed. Furthermore, a strategic national security management framework should be developed and properly implemented alongside investment-friendly policies.

The government must engage professionals in the crafting and implementation as well as the monitoring of development plans. It must also follow through and ensure the transparent and accountable management of the recovered stolen funds while the law enforcement agencies should be strengthened. The positions in the legislative arm of government should be held on part-time basis in the three tiers of government.

When these steps are taken, the country's population would stabilize, more infrastructure and other social services would be provided and they would be more efficient thereby improving the wellbeing of the people. Also, more investments would be attracted thereby reducing unemployment, poverty and inequality, and sustainable development will be achieved.

\subsection{Conclusion and Recommendations}

Unequivocally, there is endemic corruption in Nigeria and this must be fought to a standstill in order to achieve sustainable development. This menace has eaten severely into the fabric of the Nigerian society. It is therefore recommended that all hands must be on deck to win this battle, and the government must demonstrate political will in this fight. The government agencies should also be mandated to enlighten the public on the elements of sustainable development and the accruable benefits upon its achievement. A strict implementation of these recommendations would fast-track sustainable development and transform Nigeria into one of the most desirable destinations in the world.

\section{References}

Abasilim, A.N., Ayoola, A.O. and Odeyemi, A.O. (2017). Entrepreneurship: The Tool for Economic Diversification in Nigeria. Futa Journal of Management and Technology, 1(3), 104-112.

Abayomi, M. A. and Akinwunmi, A. A. (2016). Corruption: Obstacle to Sustainable Development in Nigeria. Journal of Educational Research in Natural and Social Sciences, 1(2), 34 - 48.

Abayomi, M.A. and Omoyeni, J.A. (2015). The Growing Incidence of Poverty in Nigeria: Triggers, Consequences and Turnaround Strategies. Journal of Educational Research in Natural and Social Sciences (JERNASS). Vol. 1, No. 1.

Aidt, T.S. (2010). Corruption and Sustainable Development. Chapter prepared for "International Handbook on the Economics of Corruption (2011), Volume 2, Susan Rose-Ackerman and Tina Soreide, (eds.), Cheltenham UK: Edward Elgar. Availaible at www.econ.cam.ac/repec/cam/pdf. 
Fashola ,M.A. (2001). Macroeconomic Theory, Highlights and Policy Extensions for Less- Developed Economies. Lagos. Concept Publications Ltd.

Jhingan, M. L. (2006). The Economics of Development and Planning (38th Ed). Delhi: Virnda Publication (P) Ltd.

Lewis, W.A. (1954). Economic Development with Unlimited Supplies of Labour. Manchester School, May. Reprinted in The Economics of Underdevelopment (ed.) Aggrawal, A.N. and S.P. Singh pp.400-449.

Lucas, R. (1988). On the Mechanics of Economic Development. Journal of Monetary Economics, 22, 2-42.

Nnanna, O. J., Englama, A., and Odoko, F. O. (Eds.) (2004). Financial Markets in Nigeria. Abuja: Kas Arts Service.

Nurkse, R. (1955). Problems of Industrialisation of Eastern and South-Eastern Europe in Aggarwal and Singh.

Nwanyanwu, J. (2010). An Analysis of Banks' Credit on the Nigerian Economic Growth (1992-2008). Jos Journal of Economics, 4(1).

Oyesola, B. (2016). Nigeria Groans as Africa's Largest Economy battles Recession. The Sun News. Available online at https://sunnewsonline.com/nigerians-groan- as-africa-largest-economy-battles-recession/amp/.

Pearce and Warford (1993).World Without End: Economics, Environment and Sustainable Development. New York and Oxford: Oxford University Press.

Rebelo, S. (1991). "Long-run Policy Analysis and Long-run Growth. Economic Journal, Vol. 38, 543-559.

Romer (1986) In Nwachuckwu, J.(2010) An Analysis of Banks' Credit on the Nigerian Economic Growth (1992-2008). Jos Journal Of Economics, Vol.4, No.1.

Rosenstein-Rodan, P.N. (1943). Notes on the Theory of "Big Push" in Economic Development of Latin America (ed) H.S. Ellis and W.W. Wallich, 1961.

Singer, H.W. (1970): "Dualism Revisited": A new Approach to the Problems of Dual Societies in Developing Countries". Journal of Development Studies 7, 60-61 in Todaro, M. P. and Smith, S. C. (2006). Economic Development. (9th Ed). England: Pearson Education Limited.

The Sun (2016). "Nigeria is a Fantastically Corrupt Country" by David Cameron. Available at sunnewsonline.com/Nigeria-is-fantastically-corrupt-country [para 2]

Todaro, M.P. and Smith, S.C. (2011).Economic Development. England: Addison-Wesley, $11^{\text {th }} \quad$ Edition.

Transparency International (2018). Nigeria's Corruption Perceptions Index. Accessed on $28^{\text {th }}$ August, 2018 at https://www.transparency.org/country/NGA.

World Bank (1997). Helping Countries Combat Corruption: The Role of the World Bank. Washington DC. World Bank Group.

World Commission on Environment and Development [Brundtland Commission] (1997). Our Common Future. New York: Oxford University Press. Retrieved from Wikipedia https//en.m. wikipedia.org on $24^{\text {th }}$ February, 2016.

York, G. (2015). Nigeria's Oil-Dependent Economy Plagued by Plunging Crude Prices. The Globe and Mail, Available at https://www.the globeand mail.com/report-on-business/international-business/nigerias-capitalfeels-the-pinch-from-the-the-plunge-in-oil-prices/article22847527/\%3F. 